\title{
Does Intellectual Capital Affect the Competitiveness of Public Accounting Firms in Indonesia?
}

\author{
Jessica Natalia Salim*, Fely Julia Christina Hartanto, Irene Shania, Devie Devie \\ Business Accounting \\ Petra Christian University \\ Surabaya, Indonesia \\ *jessicanataliak@gmail.com, felyjulia@gmail.com, ireneshania7@yahoo.com, ddeviesa@yahoo.co.id
}

\begin{abstract}
The purpose of this paper is to understand the relationship between Intellectual Capital, Organization Learning, and Competitive Advantage considering Information Technology Investment in Public Accountant Firm. Data were collected from 391 Public Accounting Firms registered in the Ministry of Finance of the Republic of Indonesia as of January 2019. The survey was sent by email and a total of 51 valid questionnaires were obtained and used to test the research model. This paper adopts Statistical Product and Service Solutions (SPSS) and Partial Least Square (PLS) program to test the direct effect and moderating effect of the variables. The result finds that Intellectual Capital and Organization Learning are significant factors in creating a Public Accountant Firm's competitive advantage. The moderating effect of Information Technology Investment on Intellectual Capital and Competitive Advantages is also confirmed. Practical Implications This research can provide benefits for Public Accountant Firms to know the implications of Intellectual Capital, Organization Learning, and Information Technology Investment in improving the Competitive Advantage of a firm.
\end{abstract}

Keywords: Intellectual Capital, Organization Learning, Information Technology Investment, Competitive Advantage

\section{INTRODUCTION}

The ever-developing world of the economy is being further supported by globalization. Globalization makes it free and quick for everyone to trade information as well as do transaction [1], which is called as a borderless global economy [2]. This globalization phenomenon pushed the Association of Southeast Asian Nations (ASEAN) to create a movement called the Asean Economic Community (AEC) which is an economic integration by creating a free trade system between ASEAN countries. Through AEC, the ASEAN countries agreed upon the Mutual Recognition Arrangements (MRAs), a framework that facilitates the exchange of professional services in ASEAN region that includes 8 professions: engineering service, nursing service, architectural service, mutual recognition of surveying qualification, dental practitioner, medical practitioner, tourism professional, and accountancy service [3]. The accountancy service is one profession that will receive the impact. According to Perera et al. [4], accounting firms are the one who got exposed the most by the power of globalization. On the other hand, globalization could create opportunities for public accounting firms to enter the international market and compete with other countries' public accounting firms [5]. This situation creates a hypercompetitiveness condition that causes companies' survivability issues to be considered important [6].

Barney [7] observed that the increase of investment and the management of strategic assets that are valuable, rare, and hard to imitate are the answers to the competitive challenges. That characteristic corresponds to the definition of intellectual capital that is said to be hard to imitate by competitors [7-8]. Hitt et al. [9] supported that statement by arguing that intellectual capital is more superior than tangible resources in creating competitive advantage. Public accounting firms run in the service sector, where the firms have to understand the market. Because of that, public accounting firms need the role of relational capital to be able to own information about their customers and competitors. Aside from that, the high instances of the job change $(56,3 \%)$ in Indonesian public accounting firms [10], which implies a high turnover rate, shows that public accounting firms still cannot see their employees as "assets". Meanwhile, public accounting firms also need employees, because the competency, innovation, experience, tacit knowledge, and commitment of an employee will bring benefits to public accounting firms, which contained in a component of Intellectual Capital: Human Capital.

Aside from that, the business world has shifted into the stage of Industry 4.0. In this stage, businesses are demanded to be able to follow the development by developing their IT, so they have to start investing in their IT. Lowe et al. [11] stated that information technology is being used to increase the effectivity and efficiency in Public Accounting Firms. However, some research stated that IT alone is not enough to create a competitive advantage [12-14]. Tippins and Sohi [15] also stated that investment in IT cannot directly increase a company's productivity and profitability; thus, investment on IT cannot directly create competitive advantages [16]. The second factor that affects the creation of competitive advantage is organization learning. According to Lien et al. [17] organization learning related to the organization's capacity to change and learn continuously and in the end changes the organization to a higher level of performance. On its relation to PAF (Public Accounting Firms), the accounting rules that become the foundation of PAF keep undergoing changes and 
thus demanded PAF to keep studying and following those changes.

In business competition, there will always be people who copied the innovations that a company made, thus companies have to always develop their skills in order to protect their position [18]. This can be handled if the company has organization learning, which is an organization ability to manage standard resources into unique competency that is hard to be duplicated by competitors. Hsu and Fang [19] said that organization learning is highly influenced by intellectual capital (human capital, structural capital, and relational capital). Barney [7] supported that statement by saying that organization learning could help firms in collecting and using valuable and rare resources (Intellectual Capital) so that the organization could gain a sustainable competitive advantage.

This research is the only one that combines intellectual capital and organization learning variables in creating Competitive Advantage by considering information technology investment. This research is expected to bring benefits for practitioners to know the roles of intellectual capital, organization learning, information technology investment in creating the advantage of Public Accounting Firms so that those firms can consider those development factors more.

\section{A. Intellectual Capital on Organization Learning}

In Intellectual Capital there is the Human Capital that consists of the learning ability of a firm's employees. According to Curado and Bontis [20], the learning ability of each employee, when being put together, is organization learning. Argyris [21] also said that organization learning can happen when an employee acts as a learning agent that could respond to internal and external changes, as well as learn something new. Thus, it can be said that organization learning is affected by Human Capital. The role of Structural Capital is as a provider of infrastructure so that the employees can have a higher capability [22], and a "knowledge deposit" that can facilitate the knowledge exchange within a company [23]. Also, companies do not only receive information internally but also externally, and in this situation, Relational Capital takes its role. Relational capital can be understood as the ability of a company in keeping a positive relationship with the business community [23]. Where according to Smith [24], through that relation companies can spillover, accumulates, and diffuse their knowledge. Relation between Intellectual Capital and organization learning also supported by Ya and Fang's [25].

H1: Intellectual Capital has a positive relationship with Organization Learning in Indonesian Public Accounting Firms

\section{B. Organization Learning on Competitive Advantage}

Organization learning can help organizations in gathering and utilizing their resources. This statement is supported by Karash' [26] research which identified that organization learning help transform standard resource into unique competency that cannot be easily duplicated. On the other hand, the newest literatures show that organization learning is a special and complex skill that is hard to be copied or transferred, of which this is the main source of the creation of Competitive Advantage [8]. Garvin et al. [27] stated that higher rate of learning is positively related to competitive advantage. Organization learning does not only become an option but a core requirement for organizations in order to compete successfully [28]. Organization learning help to adapt faster than its competitors in an unpredictable environment.

\section{H2. Organization Learning has a positive relationship with Competitive Advantage in Indonesian Public Accounting Firms}

\section{Intellectual Capital on Competitive Advantage}

In modern business, physical assets are no longer considered as the most strategic assets because every company could achieve that [29], thus, another strategic asset is needed to create Competitive Advantage. Stewart's [30] agreed to the statement that Intellectual Capital is an invisible but powerful asset to create Competitive Advantage. The relation strengthened by the findings of several researchers with positive relationship results between intellectual capital and competitive advantage [31-33]. However, the previous research had not yet studied the Public Accounting Firms sector that has to be able to compete globally to catch the opportunity nowadays. Thus, this research will study the influence of this in Public Accounting Firms sector.

\section{H3: Intellectual Capital has a positive relationship with Competitive Advantage in Indonesian Public Accounting Firms}

\section{IT Investment Moderated the Relationship between Intellectual Capital and Competitive Advantage}

In the process of forming Competitive Advantage, Intellectual Capital will be helped more with the presence of IT. According to Santis and Presti [34] with IT, human capital management's activity quality increased. Aside from that, IT can help companies increase their relational capital by integrating the company's data supply chain so that the relationship can be formed more effectively and created Competitive Advantage [34]. Previous works of literature also show that technology can increase structural capital by increasing the learning process of an organization [35]. This will then enable the transformation of individual's knowledge that is embedded in the human capital, structuring the knowledge, which appears in organization's routine that is consisted in Structural Capital. However, Powell and DentMicallef [16] stated that investment in IT cannot directly create competitive advantages. Thus, this research will research the influence of IT investment in moderating the relationship between Intellectual Capital and Competitive Advantages in Public Accounting Firms.

H4: IT investment moderated the relationship between Intellectual Capital and Competitive Advantages in Indonesian Public Accounting Firms 


\section{Design AND METhodology RESEARCH}

In this research, Intellectual Capital will be divided into Human Capital, Relational Capital, and Structural capital. The measurement items of Intellectual Capital is developed from previous research, which is the measurement items of Sharabati et al. [36], where Human Capital adopted all 4 measurement items, while Relational Capital and Structural Capital each adopted 2 items with the highest loading factor.

Organization learning measurement is based on previous research done by Tohidi et al [37] that summarized the organization learning measurement of several researchers into five dimensions: managerial commitment and empowerment [38-40], experimentation [38-40], risk-taking [40], interaction with the external environment [40-41], and knowledge transfer and integration [38-40].Each dimension has its own measurement items, the researcher chooses two items on each dimension that have the highest loading factor, 10 items were adopted. IT Investment measurement refers to Sakaguchi and Dibrell [42] that used two items, the company's commitment to keep investing in technology and the percentage of IT investment to the company's net income. The choosing of this questionnaire's measurement items was done by experts of related field.

Competitive advantage measurement used the measurement that is based on the research of Barney [7], Coyne [43], and Porter [44] that consists of 11 question items, 4 of which that are chosen in this research are: (1) the company has the competitive advantage of low cost compared to its major competitors; (2) the quality of the services that the company offers is better than its major competitors; (3) the company is more capable of $\mathrm{R} \& \mathrm{D}$ and innovation than its major competitors; and (4) the company has better managerial capabilities than its major competitors. The researcher uses this measurement because Porter [45] argued that the power of a company is placed on one of two things: low cost or differentiation.

This research is a quantitative research that uses primary data. Questionnaires are given to all public accounting firms registered in the Ministry of Finance of the Republic of Indonesia as of January 2019. That population of 470 is then being filtered in order to get research samples with the following criteria: (i) have their email registered on the Ministry of Finance of the Republic of Indonesia (ii) the email should be valid, these criteria are chosen because we used email to give the questionnaires in order to reach the respondents. The number of samples is 390 and the final respondents of this research are 51 public accounting firms from all over Indonesia. The public accounting firms' distribution can be seen in TABLE 1 .

TABLE I. PAF RESPONDENTS’ DISTRIBUTION

\begin{tabular}{|l|l|}
\hline \multicolumn{1}{|c|}{ Province } & \multicolumn{1}{c|}{ Qty } \\
\hline Bali & 4 \\
\hline Banten & 1 \\
\hline Bengkulu & 1 \\
\hline Jakarta & 21 \\
\hline West Java & 8 \\
\hline Central Java & 4 \\
\hline
\end{tabular}

Table 1. Cont.

\begin{tabular}{|l|l|}
\hline East Java & 4 \\
\hline Lampung & 2 \\
\hline Maluku & 1 \\
\hline Papua & 1 \\
\hline Riau & 3 \\
\hline South Sumatra & 1 \\
\hline Yogyakarta & 1 \\
\hline
\end{tabular}

The questionnaire is designed by using a five-point Likert scale where 1 is strongly disagree and 5 is strongly agree. The test is done by using SPSS. The tests are the multivariate analysis, reliability test, and validity test. The next step, the data will be processed with Partial Least Square (PLS).

\section{RESULTS AND ANALYSIS}

The multivariate analysis is done to all variables, however, the downsizing of variables has to be done only on intellectual capital. Eight intellectual capital items (IC1-IC8) experienced merging that resulted in IC11 and IC12. As can be seen in TABLE II Component 1 , items with a value above 0.5 are merged into IC12, which is IC5-IC8. The same is also done to the Component 2 column, IC1-IC4 merged into IC11. The downsizing is done to reduce the variable dimension while still showing the diversity of the original variables.

TABLE II. INTELlECtUAl CAPITAL's Multivariate ANALYSIS RESULT

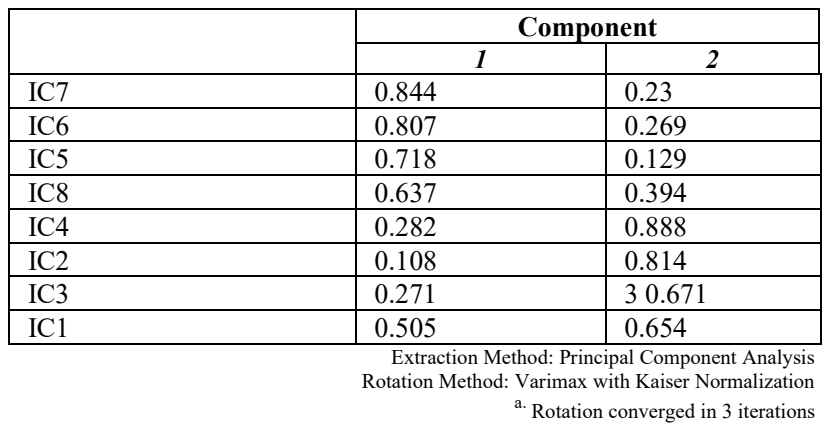

The reliability test is done to all variable measurements using Cronbach's alpha value coefficient. Hilton and Brownlow [46] also stated that if alpha $>0,90$ then it is a perfect reliability; if alpha $0,70-0,90$ then high reliability; if alpha 0,50-070 then moderate reliability; and if alpha $<0,50$ then low reliability. In this research, only IT Investment has alpha $<0.7,3$ other variables have Cronbach alpha $>0,7$.

The validity test describes how good the gathered data is in reflecting the condition that is meant to be measured [47-48]. To test the validity of the questionnaire, the researcher uses the Pearson Product Moment Correlations by using SPSS. The validity test is done by comparing $r$ count and $r$ table, if $r$ count is bigger than $r$ table then that item is declared as being able to measure the existing condition accurately [49]. The items in this research have been tested and declared valid.

Mean variable in this research ranging from 3.049 to 4.076 with 0.512 to 0.844 deviation standard. It can be said that the 
deviation standard is relatively low compared with mean, so it can reflect the existing reality [50-52]. Aside from that, the skewness and kurtosis from this research's variables range between -0.025 to 0.09 and -0.674 to 0.086 where this result has followed the standard criteria of skewness $(-3$ to +3$)$ and kurtosis $(-8$ to +8$)$ in accordance with Kline [53].

According to the test result, the relationship between variables in research can be understood by processing the data with PLS. The result and the model can be seen in FIGURE 1. From that result, it can be seen that the relationship between Intellectual Capital and Organization learning is positive and significant in the Public Accounting Firm $(\mathrm{p}<0,01)$, thus supported H1. This result indicates that Intellectual Capital will increase a company's Organization Learning. This result is in accordance with the previous research, Ya and Fang [25], where three Intellectual Capital components significantly influence a company's Organization Learning. Then, the relationship between Organization learning and Competitive advantage is positive and significant $(\mathrm{p}<0,01)$, thus if a Public Accounting Firm has Organization learning, it will significantly improve its competitive advantages, thus, $\mathrm{H} 2$ is accepted. This result is in accordance with the research that was done by Garvin et al. [27], companies that have concrete learning process is capable of ensuring that they value innovation, knowledge improvement practices, and effective problem solving and thus creating advantages if compared to their competitors. The relationship between Intellectual Capital and Competitive Advantage is positive and significant $(p=0,03)$ thus it can be concluded that if a Public Accounting Firm has a good Intellectual Capital, it will create a better competitive advantage thus $\mathrm{H} 3$ is confirmed. This is in accordance with the perspective of Barney [7] and Prahalad and Hamel [8] who stated that Intellectual Capital, including resources, valuable and rare skills that cannot be replaced represents the formation of sustainable competitive advantage and companies' superior performances. From FIGURE 1, it is also found that IT investment is capable of positively and significantly moderating the relationship between Intellectual Capital and Competitive Advantage $(\mathrm{p}<0.01)$ in Indonesian Public Accounting Firm, and thus supported H4. This is in accordance with previous research that IT Investment is significantly contributing in employees' decision process in all levels [54], a more structured system [35], and increasing the relationship with distributors and suppliers [55].

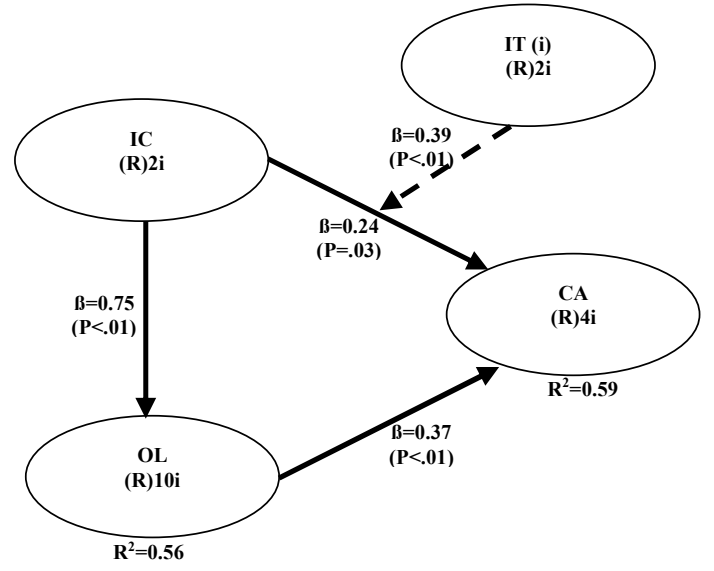

Fig. 1. Research model and result.

\section{DISCUSSION}

The development of the business environment creates the growth of competition that makes Indonesian Public Accounting Firms realize the importance of competitive advantage. They have to know the processes and understand factors that influence the creation of competitive advantage. This research wants to prove the relationship models between intellectual capital and organization learning to the creation of competitive advantage by considering IT investment. The test result shows that the four hypotheses are accepted. It can be concluded that Public Accounting Firms' Organization Learning will be improved, by improving the quality of their Intellectual capital starting from the Human Capital that consists of the companies' employees as the main driving force of the company, Structural Capital to support information exchanges in a company, and Relational Capital to receive external information as a material for Organization Learning. We can also conclude that Public Accounting Firm with good Intellectual Capital will form a better competitive advantage. Managers have to start focusing on intellectual capital because intellectual capital is an intangible resource that is hard to duplicate, valuable, and, above all that, specific to the company that supported sustainable competitive advantages.

Public Accounting Firms that have Organization Learning will improve their competitive advantages significantly. Because in dynamic environment, companies have to adapt to environmental changes by keep on improving and learning. Organization learning does not just appear out of nowhere but is shaped from the concrete learning efforts, therefore managers must begin to develop learning processes and create effective and sustainable learning culture. IT investment successfully moderating the relation between intellectual capital and competitive advantage, therefore focusing solely on IT investment will not be able to create competitive advantages, IT investment will only be able to strengthen the creation of Competitive Advantages by improving the companies' Intellectual Capital.

However, This research does not consider the public accounting firms affiliation with foreign party. .In this research the measurement of IT Investment still have moderate reliability, that indicates inconsistency in the research data. However, this result can still be accepted. The future research should consider public accounting firms affiliation with foreign party, because this can affect the research result as firms that are affiliated with foreign party tend to have more appreciation on organization learning and intellectual capital. The next research can formulate a more reliable measurement of IT Investment so that the result will be more consisten

\section{REFERENCES}

[1] Paliwoda ,S. J and Salter, S. (2009),"Globalisation through the kaleidoscope ", International Marketing Review Vol. 26 Nos 4/5, 2009 pp. 373-383.

[2] Ndhlovu, T. P. (2012)."Globalization: a theoretical reflection". World Journal of Entrepreneurship, Management and Sustainable Development, Vol. 8 Iss 2/3 pp. 95 - 112

[3] Invest In ASEAN. (n.d.). ASEAN Mutual Recognition Arrangements. Retrieved from http://investasean.asean.org/index.php/page/view/aseanfree-trade-area-agreements/view/757/newsid/868/mutual -recognitionarrangements.html 
[4] Perera, H.B., Rahman, A.R. and Cahan, S.F. (2003), "Globalization and the major accounting firms", Australian Accounting Review, Vol. 13 No. 1, pp. 27-37.

[5] Tarigan, J. and Devie. (2012). The Readiness of Local Public Accounting Firms to Globalization. Journal of Applied Business and Economics vol. 13(1), pp. 111-119

[6] Devie, D., Kamandhanu, J., Tarigan, J. and Hatane, S.E. (2019) 'Do environmental performance and disclosure bring financial outcome? Evidence from Indonesia', World Review of Science, Technology and Sustainable Development, Vol. 15, No. 1, pp.66-86

[7] Barney, J. (1991). Firm Resources and Sustained Competitive Advantage. Journal of Management, 17(1), 99-120. https://doi.org/10.1177/014920639101700108

[8] Prahalad, C.K. and Hamel, G (1990). The core competence of the corporation. Harvard Business, Vol. 68 No. 3, pp. 79-91.

[9] Hitt, M.A., Bierman, L., Shimizu, K. and Kochhar, R. (2001), "Direct and moderating effects of human capital on strategy and performance in professional service firms: a resource- based perspective", Academy of Management Journal, Vol. 44 No. 1, pp. 13-28.

[10] Sulistiyo, H. (2017). Studi Turnover Auditor Kantor Akuntan Publik di Indonesia berdasarkan Jenis Kelamin, Tingkat Pendidikan, Jabatan dan Kota.. Jurnal Ekonomi Manajemen dan Akuntansi, No.43, pp 49-58

[11] Lowe, D.J., Bierstaker, J.L., Janvrin, D.J., and Jenkins, J.G. (2017). "Information technology in an audit context: have the big 4 lost their advantage?", Journal of Information Systems, Vol. 32, No. 1, pp. 87-107

[12] Xiande, F. L and Wang, Z. Q, (2006),"The impact of information technology on the competitive advantage of logistics firms in China", Industrial Management \& Data Systems, Vol. 106 Iss 9 pp. 1249 -1271

[13] Breznik, L. (2012). Can information technology be a source of competitive advantage?. Economic and Business Review, Vol. 14 No. 3, pp. 251-269.

[14] Vlaar, Paul W.L., Frans A.J. Van den Bosch, Henk W. Volberda. (2015). "On the relation between information technology and interorganizational competitive advantage: a competence perspective" Competence Perspectives on Managing Interfirm Interactions.

[15] Tippins, M. \& Sohi, R. (2003). IT competency and firm performance: Is organizational learning the missing link? Strategic Management Journal, 24 (8), 745-761.

[16] Powell, T. C. and Dent-Micallef, A. (1997). Information Technology as Competitive Advantage: The Role of Human, Business, and Technology Resources. Strategic Management Journal, Vol. 18:5, 375-405

[17] Lien, B., Hung, R. and McLean, G. (2007), "Organisational learning as an organisation development intervention in six high-technology firms in Taiwan: an exploratory case study", Human Resource Development Quarterly, Vol. 18 No. 2.

[18] Wernerfelt, B. (1984). A resource-based view of the firm. Strategic Management Journal, 5(2), 171-180. doi:10.1002/smj.4250050207

[19] Hsu, Y.H., \& Fang, W. (2009). Intellectual capital and new product development performance: The mediating role of organizational learning capability. Technological Forecasting and Social Change, 76(5), 664677. doi:10.1016/j.techfore.2008.03.012

[20] Curado, C. and Bontis, N. (2007), "Managing intellectual capital: the MIC matrix", International Journal of Knowledge and Learning, Vol. 3 No. 3, pp. 316-328.

[21] Argyris,C. (1991), "Teaching smart people how to learn", Harvard Business Review,Vol.69 No.3, pp. 99-109.

[22] Cabrita, M. and Bontis, N. (2008), "Intellectual capital and business performance in the portuguese banking industry", Int. J. Technology Management, Vol. 43 Nos 1-3, pp. 1-26.

[23] Ramezan, M., (2012),"Measuring the knowledge productivity", Education, Business and Society: Contemporary Middle Eastern Issues, Vol. 5 Iss 3 pp. 200

[24] Smith, K.A., Vasudevan, S.P., and Tanniru, M.R. (1996). "Organizational learning and resource-based theory: an integrative model", Journal of Organizational Change Management, Vol. 9 Issue: 6, pp.41-53, https:// doi.org/10.1108/09534819610150512

[25] Ya, H. and Fang, W. (2008).Intellectual capital and new product development performance : The mediating Role of organizational learning capability. Technological Forecasting and Social Change Journal, Vol. 66 , pp.664-677.

[26] Karash, R. (2002). The Society for Organizational Learning. London: Solonline pub

[27] Garvin, D. A., Edmondson, A. C., \& Gino, F. (2008). Is yours a learning organization?. Harvard business review, 86(3), 109.

[28] Singh, M.D. and Kant, R. (2008), "Knowledge management barriers: an interpretive structural modeling approach", International Journal of Management Science and Engineering Management, Vol. 3 No. 2, pp. 141-150

[29] Goh, S.C. and Ryan, P.J. (2005), "Learning capability, organizational factors and firm performance", paper presented at the 3rd European Conference on organizational knowledge, learning and capabilities, Athens, 56 April.

[30] Stewart, T.A. (1997), Intellectual Capital: The New Wealth of Organizations, Bantam Doubleday Dell Publishing Group, New York, NY.

[31] Tseng, K.A. et al. (2013). Mediation of strategy on intellectual capital and performance. Management Decision, Vol. 51,No. 7,pp. 1488-1509.

[32] Kamukama, N. (2013). Intellectual capital: company's invisible source of competitive advantage. International Business Journal, Vol 23, No. 3, pp.

[33] Chen, Y.S. (2008). The positive effect of green intellectual capital on competitive advantages of firms. Journal of Business Ethics, Vol. 77, pp. 271-286.

[34] Santis, F.D. and Presti, C. (2018). "The relationship between intellectual capital and big data: a review", Meditari Accountancy Research, https://doi.org/10.1108/MEDAR-10-2017-0222

[35] Higgins, J. (2014), "Bringing HR and finance together with analytics", Society for Human Resource Management-HR Magazine, Vol. 59 No. 11, pp. 11-13.

[36] Sharabati, A.A., Jawad, S.N. and Bontis, N. (2010), "Intellectual capital and business performance in the pharmaceutical sector of Jordan", Management Decision, Vol. 48 No. 1, pp. 105-131.

[37] Tohidi, H. Seyedaliakbar, S. M., and Mandegari, M. (2011). Organizational learning measurement and the effect on firm innovation", Journal of Enterprise Information Management, Vol. 25 Iss: 3 pp. 219 245

[38] Banutu-Gomez, M.B. (2004), "Great leaders teach exemplary followership and serve as servant leaders", The Journal of the American Academy of Business, Vol. 4 No. 1, pp. 143-52.

[39] Goh, S.C. and Richards, G. (1997), "Benchmarking learning capabability of organization",European Management Journal, Vol. 15 No. 5, pp. 575-83.

[40] Chiva, E. and Delorme, S. (2004), "The performance of motivational command agents in a command post training simulation", Proceedings of the 2004 Conference on Behavior Respresentation in Modeling and Simulation.

[41] Templeton, G.F., Lewis, B.R. and Snyder, C.A. (2002), "Development of a measure for the organizational learning construct", Journal of Management Information Systems, Vol. 19 No. 2, pp. 175-218.

[42] Sakaguchi, T. and Dibrell, C. (1998). "Measurement of the intensity of global information technology usage: quantitizing the value of a firm's information technology", Industrial Management \& Data Systems, Vol. 98 Iss 8 pp. $380-394$

[43] Coyne, K. P.(1986), 'Sustainable Competitive Advantage - What It Is, What It Isn't', Business Horizons 29(1), 54-61.

[44] Porter, M.E. (1980) Competitive Strategy: Techniques for Analyzing Industries and Competitors. Free Press, New York.

[45] Porter, M.E. (1985), Competitive Advantage, Free Press, New York, NY.

[46] Hilton,P.R. and Brownlow, C. (2004). SPSS Explained. East Sussex : Routledge

[47] Ghauri, P. and Gronhaug, K. (2005). Research Methods in Business Studies, Harlow, FT/Prentice Hall.

[48] Field, A. P. (2005). Discovering Statistics Using SPSS, Sage Publications Inc.

[49] Malhotra, N.K. (2012). Basic Marketing Research. Prentice Hall 
[53] Kline, R. B. (1998). Methodology in the social sciences : Principles and Practice of Structural Equation Modeling. New York, NY: The Guilford Press.

[54] Shah, H., Aziz, A., Jaffari, A. R., Waris, S., Ejaz, Brands on Consumer Purchase Intentions, Asian Journal of Business Management 4(2): 105110

[55] McGuire, S. and Ladd, B. (2014), "BD and human capital management", Workforce Solutions Review, Vol. 5 No. 2, pp. 30-31. 